\title{
IMPACT OF VARYING THROAT DIAMETER IN THE VENTURI SYSTEM ON THE AERATION EFFICIENCY
}

\author{
Ahmed Helmy Mahmoud*1 and Mamdouh Ahmed Dardeer ${ }^{1}$ \\ ${ }^{1} \mathrm{Al}$-Azhar University, Faculty of Engineering, Civil Engineering Department, Cairo, Egypt \\ *Corresponding Author's E-mail: hmedbadr3000@ hotmail.com \\ Received: 31 March 2021 Accepted: 04 June 2021
}

\begin{abstract}
Venturi tube is an applicable and economic alternative device to transfer gas-liquid. It is simply designed easily manufactured and it does not need maintenance. The process of air vacuum through venturi tube has been used widely in many agricultural, industrial and the process of water purification (e.g. chlorine and ozone injecting for drinking water, injecting chemicals as liquid fertilizers in the system of sprinkler irrigation/ transferring dissolved oxygen in drinking water and waste water treatment). The main objective of this research is to evaluate effect of geometric characteristics on the aeration efficiency in the venturi system. To achieve this goal, the venturi is designed and carried out, from transparent polycarbonate. Experiments were conducted on clear-water conditions at different discharges $\left(\mathrm{Q}_{\text {water }}\right)$ : 44.16 , $58.88,73.59$ and $88.31 \mathrm{lit} / \mathrm{min}$ which correspond to four inlet velocities (v): 1.5, 2.0, 2.5 and $3.0 \mathrm{~m} / \mathrm{s}$. The study involved selecting three different throat diameters $\left(\mathrm{d}_{\mathrm{t}}\right): 10,12.50$ and 15 $\mathrm{mm}$, and three different air inlets orifices diameters $\left(\mathrm{d}_{\mathrm{s}}\right): 3,5$ and $8 \mathrm{~mm}$. Five different outlets angles have been used $(\beta): 7^{\circ}, 10^{\circ}, 15^{\circ}, 21^{\circ}$, and $25^{\circ}$ with inlet angle $(\alpha)$ stabilization at $7^{\circ}$. The inlet and the outlet diameter $(\mathrm{D})$ and throat length $\left(\mathrm{L}_{\mathrm{t}}\right)$ in all the experiments were constants and equals to 25 and $8 \mathrm{~mm}$, respectively. The results of the study demonstrated that the throat diameter of the venturi tube affects the aeration efficiency.The best results were given for the relationship between (Qair / Qwater) $=92 \%$ with outlet angle of $25^{\circ}$ in the case of $(\mathrm{dt} / \mathrm{D}=0.4$ and $\mathrm{ds} / \mathrm{D}=0.32$ and $\mathrm{Lt} / \mathrm{D}=0.32)$. Additionally, empirical equations were gotten for venturi tubes linking air flow and water flow to throat lengths and diameters, venturi outlets angles. air inlets orifices diameters and Reynolds numbers.
\end{abstract}

Keywords: Geometric characteristics, throat dimeter, air injection, venturi, water quality.

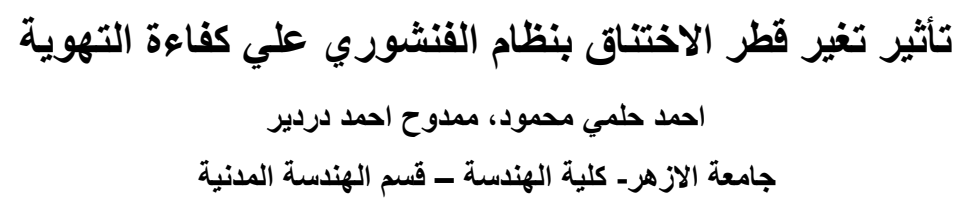

Ahmedbadr3000@hotmail.com:البريد الاككتروني للباحث الرئيسي" 


\begin{abstract}
الملخص
الفينشوري هو جهاز بديل اقتصادي قابل للتطبيق لنقل الغاز السائل. إنه مصمم ببساطة وسهل التصنيع ولا يحتاج إلى صيانة. تم استخدام عملية تفريغ الهواء من خلال أنبوب الفينشوري على نطاق واسع في العديد من العمليات الزر اعبة

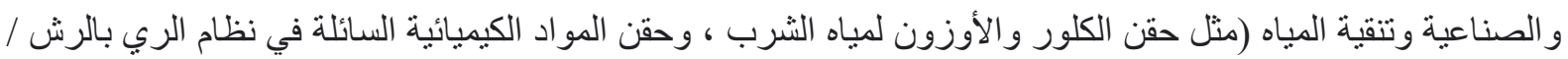
ذياره الأكسجين المذاب في المياه - معالجة المياه ومياه الصرف الصحي). الهدف الرئيسي من هذا البحث هو تقييم تأثير الخصائص الهنسية على كفاءة التهوية في نظام الفينشوري. لتحقيق هذا الهدف ، تم تصميم الفينشوري وتتفيذه ، من مادة

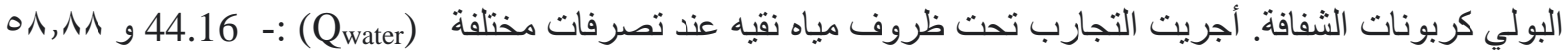

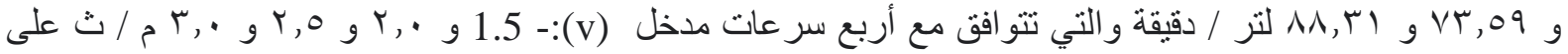

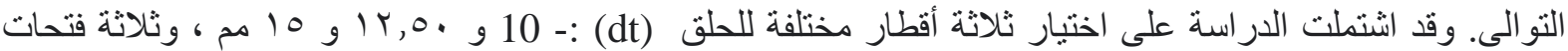

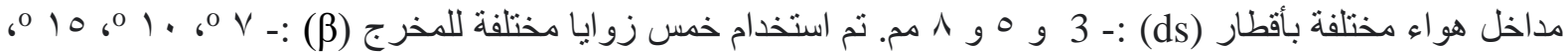

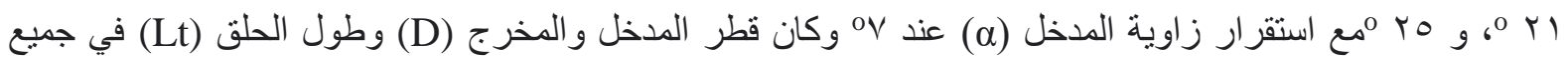
التجارب ثابت ويساوي ^ و م. مم على التوالي. وقد أظهرت نتائج الدراسة أن قطر الحلق لأنبوب الفينشوري يؤثر على كفاءة التهوية وقد أعطيت افضل النتائج للعلاقة بين (Qair/Qwater) = 92\% مع زاوية خروج 250 فى حالة (dt/D= 0.4 و 0.32=ds/D = Lt/D 0.32).بالإضافة إلى ذلك ، تم الحصول على معادلات تجريية لأنابيب الفينشوري التي تربط تدفق الهواء وتدفق المياه بأطوال وأقطار الحلق وزوايا مخرج الفينشوري وأقطار فتحات الهواء وأرقام رينولدز.
\end{abstract}

\title{
1. INTRODUCTION
}

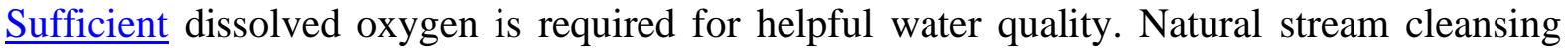
procedures need enough oxygen levels for the purpose of supply for aerobic life systems. The happening of oxygen and water mixing together is titled aeration. There are several techniques to add air or oxygen to water, for instance open air reservoirs, submergible pumps, domestic aeration systems, compressor systems and air pump systems. However, the Venturi system, relied on the easiness of Ejectors, gives a easy, preservation free aeration solution. venturi system permits air to be injected inside running water from air inlet orifices and so rises oxygen levels in the water. The venturi tube was named after Venturi, an Italian, who investigated its principle about 1791. The Venturi tube consists of three parts: the first part is the converging "contraction" part (inlet), the last part is the diverging "diffusion" part (outlet), with a cross section that shrinks and expands gradually. The middle part is the throat part (which has a cross-sectional area smaller than the tube) as in Figure 1. Rapidly converging flow, as between the inlet and throat of a venturi-tube, causes the velocity to become more uniform over the cross section. Over580 the short length involved the loss of head due to friction is negligible in comparison with difference of pressure head $\left(\left(\mathrm{p}_{1}-\mathrm{p}_{2}\right) / \mathrm{\gamma}\right)$. For a single streamline Bernoulli's equation then gives [Daugherty et al., 1985]: 


$$
v_{2}^{2}=v_{1}^{2}+2 g\left(\frac{p_{1}-p_{2}}{\mathrm{y}}\right)
$$

Where 1 and 2 are subscripts indicating points 1 and 2 ; $\mathrm{v}_{1}$ and $\mathrm{v}_{2}$ are velocities; $g$ is gravitational acceleration; $\mathrm{p}_{1}$ and $\mathrm{p}_{2}$ are pressures and $\gamma$ is specific weight.

According to Bernoulli equation (1), an orifice is created in the throat part, and with the increased velocity in this area and the decreasing pressure, the air suction is created and thus the liquid mixes with air causing bubble flow. This process is called venturi effect that results in the fluid in a vacuum clouds. The mixture is directed to an area to the Venturi diffusion zone, the velocity decreases and the pressure energy is restored, with slight friction loss to transfer the mixture to the outlet.

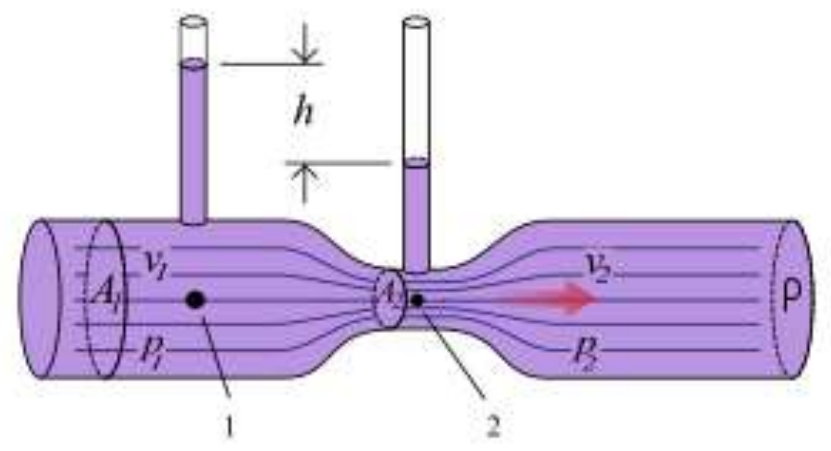

Figure 1. Variation in pressure head for venturi Tube.

Numerous studies underlined the existence of the connection between the geometric properties of the venturi tube and the aeration process efficiency. E.g.; In 2001, ReaderHarris et al., used twenty-one venturi tubes that were carried out with a diameter ratios range from 0.4 to 0.75 . These tubes were tested in high-pressure gas and water. With standard venturi tubes, they obtained an equation to the coefficient discharge in water with a 0.74 percent of doubt. The (CFD) software Ansys (FLUENT) has been used as a tool to carry out design and copying of the Venturi tube [Reader-Harris et al., 2001]. In 2003, Emiroglu and Baylar, used demonstrated that the air entrainment rates of the circular nozzles with air holes were significantly higher than those of circular nozzles without air holes [Emiroglu and Baylar, 2003]. In 2005, Bagatur declared that the systems of aeration using the venturi tube can be used to solve lack of dissolved oxygen, nitrogen and nutrient, smell in the evaporation of waste water and the excessive organic matter [Bagature, 2005]. In 2007, Zhu et al., examined the development of an aerator module with injectors of venturi tubes to develop the 
efficiency of aeration [Zhu et al., 2007]. In 2009, Baylar et al., studied the effect of the inlet hole diameter of venturi tube on the rate of air injection. This study proved that the diameter of inlet hole on venturi tube has a vital role in injecting air and there was an optimum diameter that increases injecting air [Baylar et al., 2009]. In 2012, Nithin et al., used Computational Fluid Dynamics (CFD) to count 2D loss of permanent pressure and relative pressure incompressible liquid for different patterns of a traditional venturi meter [Nithin et al., 2012].

In 2015, Dam and Sarkar carried out an ultimate concentration of DO with various rpm at various hole throat, respectively, i.e. $1 \mathrm{~mm}, 2 \mathrm{~mm}$ and $3 \mathrm{~mm}$. The fast and ultimate rates are accomplished in a time span of 480 seconds in case of $1800 \mathrm{rpm}$ of hole 3 to $1 \mathrm{~mm}$ hole throat diameter [Dam and Sarkar, 2015]. In 2017, Zhang stated that if the contraction ratio rises vacuum degree and mass flux increase. On the other hand, while the diffusion angle ascends, both mass flux and vacuum degree decrease. Additionally, increasing the contraction ratio leads to a shortage in the velocity of a fully developed part in the diffusion section. When the contraction ratio is less than 0.2 or the angle of diffusion is less than $35^{\circ}$ the velocity in the diffusion part presents a skewed and parallel flow. While the difference in the pressure rises, the mass flux also increases, so a back flowing occurs [Zhang, 2017]. In 2017, Khound et al., studied the venturi efficacy considering it as a device for aeration. Basically, the venturi depends on the geometry and the conditions of flow inside it. He studied the diameter and the holes placement in a venturi using various conditions of flow to determine the venturi performance as an aerator [Khound et al., 2017]. In 2018, Bagatur et al., carried out various modules of aerator with a venturi tube linked in either single or double in parallel (with outlet pipe line single or double). Experimentally, the results showed that the design of parallel (connected to a pipe line of a single outlet) in general carried out better than the single and double outlet [Bagatur et al., 2018]. In 2019, Sobenko et al., carried out practical investigations of venturi injectors tracking needs listed by ISO 15873; and demonstrated the injection rate utilizing dimensional analysis by the Buckingham Pi theorem. The outcomes revealed that the injection flow rate was more responsive to variations in the motive flow rate and the difference pressure when the venturi injector was controlled under low values of inlet pressure (i.e., 100 and $150 \mathrm{kPa}$ ) [Sobenko et al., 2018]. In 2020, Li et al., studied the suitable numerical simulation methods for venturi injectors, containing the examination of the hydraulic performance, mixing procedure, and the streaming law of the two internal fluids, simulations and experiments were handled in this study. This study noticed that the mixing 
chamber and throat are the main parts of energy loss. Moreover, it detected that the internal flow of the venturi injector results in the majority of mixing happening at the diffusion and outlet sections [Li et al., 2020].

This paper presents an experimental study about air injection efficiency of venturi tubes, and in particular, effect of the throat diameter of the venturi tube on the aeration process efficiency. The paper tries to reach the best design. So it allows the largest volume of air to be transported to water.

\section{DIMENSIONAL ANALYSIS}

Theoretical study has been behaved utilizing dimensional analysis method to discover the relationships between all parameters which affecting the air injection flow rate ( $\left.Q_{\text {air }}\right)$. Functional relationships are obtained between the $Q_{\text {air }}$ for all parameter. In this study: the $Q_{\text {air }}$ is the dependent variable. It can be expressed as a function of all other independent variables as follows:

$$
Q_{\text {air }}=\varphi\left(Q_{\text {water }} \rho, \mu, v, d_{s}, d_{t}, L_{t}, D, \beta, \gamma, \alpha\right)
$$

Where, $\mathrm{Q}_{\text {water }}$ is the water flow rate through the venturi, $\rho$ is the density of fluid, $\mu$ is the dynamic viscosity, $v$ is the velocity, $d_{s}$ is the hole diameter, $d_{t}$ is the throat diameter, $L_{t}$ is the throat length, and $\beta$ is the outlet angel and $\alpha$ is the inlet angle (see Figure 2).

Using Buckingham's $\pi$-Theorem, eleven variables and three repeated changes were obtained. These changes can be easily coordinated in the following non -dimensional $\pi$-terms.

$$
\begin{gathered}
\pi_{1}=\frac{Q_{\text {air }}}{v d_{t}^{2}}, \quad \pi_{2}=\frac{Q_{\text {water }}}{v d_{t}^{2}}, \quad \pi_{3}=\frac{\mu}{\rho v d_{t}}, \\
\pi_{4}=\frac{d_{s}}{D} \quad \pi_{5}=\frac{d_{t}}{D} \quad \pi_{6}=\frac{L_{t}}{D} \quad \pi_{7}=\beta \text { and } \pi_{8}=\alpha
\end{gathered}
$$

According to Buckingham Pi-theorem, the general form of relationship between these variables is written as follows:

$$
\varphi=\left(\frac{Q_{\text {air }}}{v d_{t}^{2}}, \frac{Q_{\text {water }}}{v d_{t}^{2}}, \frac{\mu}{\rho v d_{t}}, \frac{d_{s}}{D}, \frac{d_{t}}{D}, \frac{L_{t}}{D}, \frac{\beta}{\alpha}\right)
$$

Taking the properties of $\pi$-terms into account, the following equation was obtained: 


$$
\frac{Q_{\text {air }}}{Q_{\text {urater }}}=\varphi\left(R n, \frac{d_{s}}{D}, \frac{d_{t}}{D}, \frac{L_{t}}{D}, \frac{\beta}{\alpha}\right)
$$

Where, $\mathrm{Rn}$ is Reynold's number.

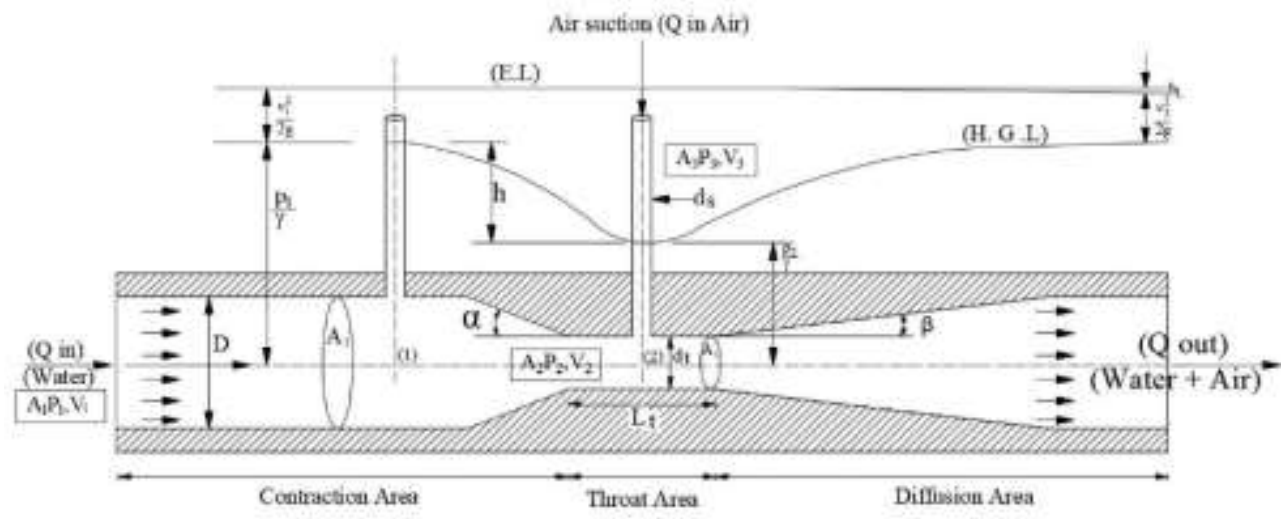

Figure 2. Definition sketch of all parameters.

\section{EXPERIMENTAL WORKS}

\subsection{Physical Modeling}

In the hydraulic laboratory of the Faculty of Engineering, Al-Azhar University, Cairo, Egypt, a testing device was constructed to achieve the goal of the investigational work as shown in Figures 3, 4. The testing device is formed mainly of water tank, pump, a valve to control the flow, the feed line of water, water digital flowmeter and a releasing valve (to control the rate of water flow). The models of the venturi tubes that were used in the experiments were manufactured from transparent polycarbonate through (CNC) as shown in Figures 5.

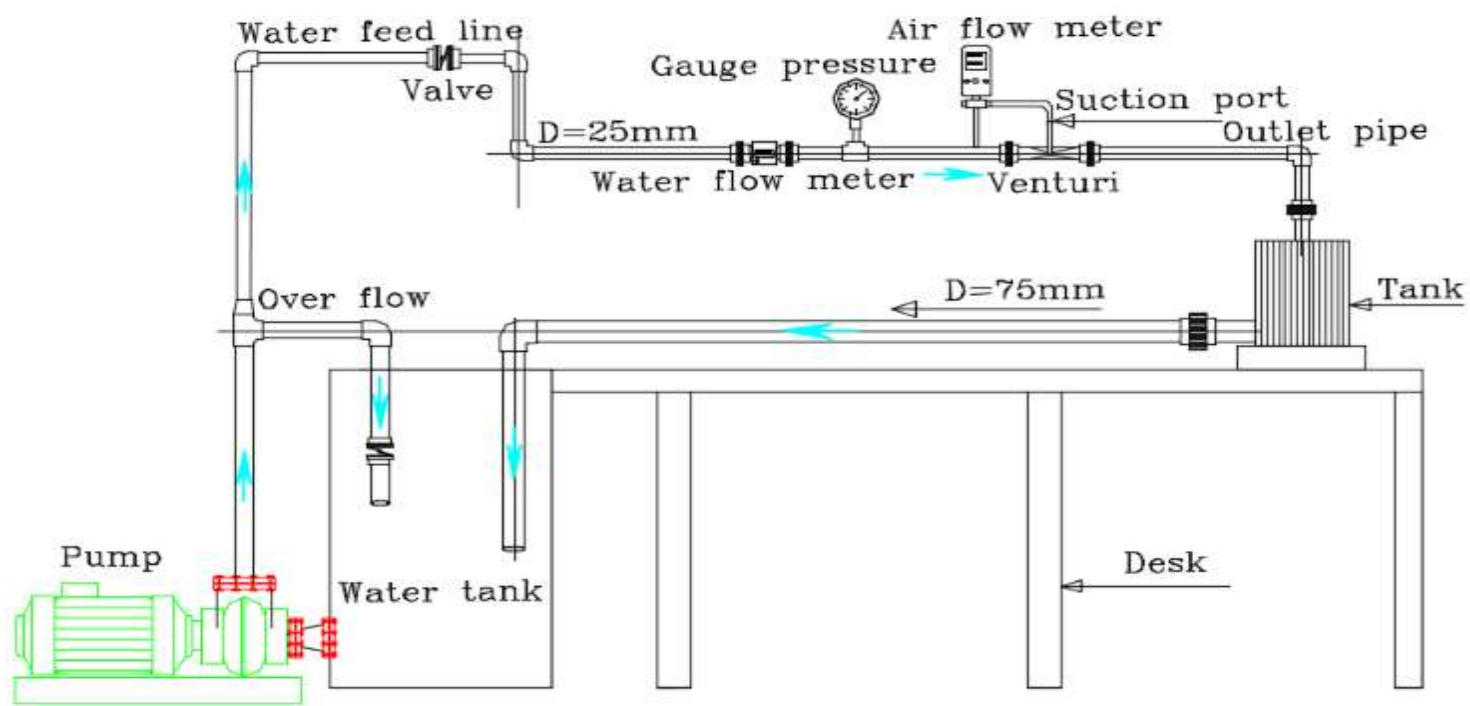


Figure 3. Schematic of the Venturi Tube Experimental Apparatus.

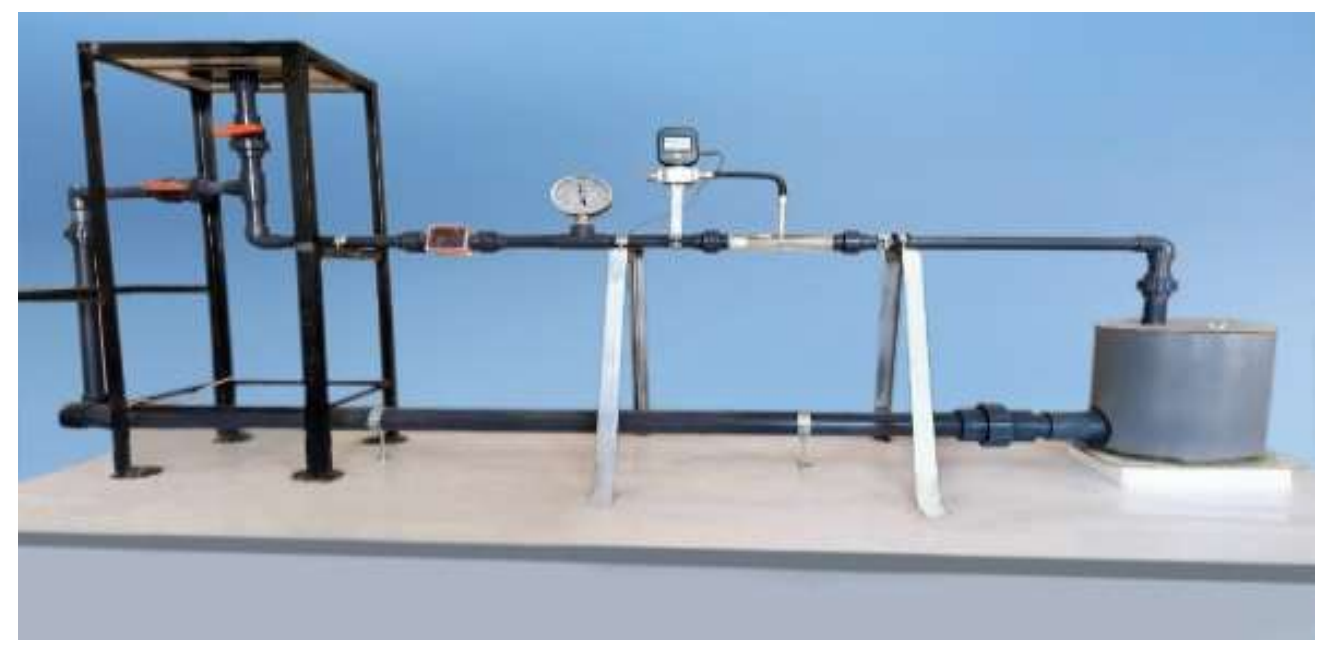

Figure 4. Photo of the experimental Apparatus.

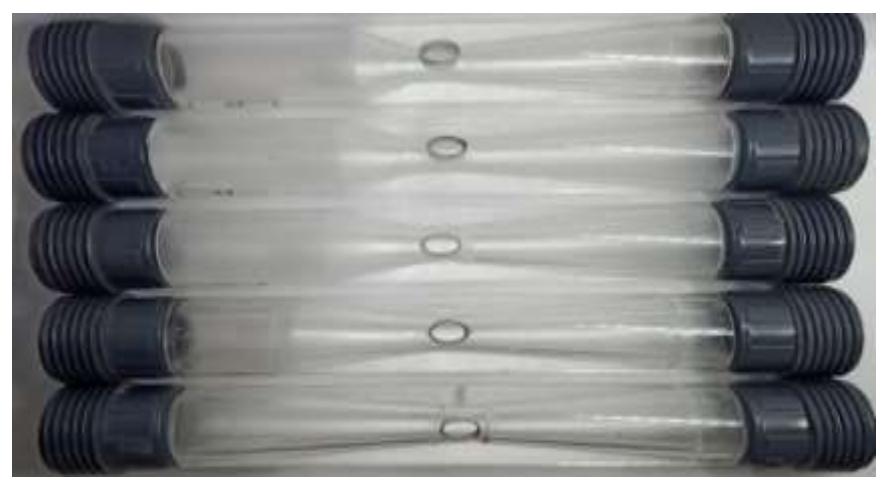

Figure 5. Photos of the Venturi Tubes (samples).

\subsection{Experimental Program}

In this investigational work 180 runs were carried out in order to evaluate effect of the geometric characteristics on the aeration efficiency in the venturi system. A thoroughly designed experimental program is carried out to investigate these models. Experiments were conducted under clear-water conditions $\left(\rho=1000 \mathrm{~kg} / \mathrm{m}^{3}\right.$ and $\mu=1.00 \times 10^{-3}$ Pa.s $)$ at different discharges $\left(\mathrm{Q}_{\text {water }}\right)$ : 44.16, 58.88, 73.59 and $88.31 \mathrm{lit} / \mathrm{min}$ which correspond to four inlet velocity (v): 1.5, 2.0, 2.5 and $3.0 \mathrm{~m} / \mathrm{s}$. The study involved selecting three different throat diameters $\left(\mathrm{d}_{\mathrm{t}}\right): 10,12.50$ and $15 \mathrm{~mm}$, and three different air inlets orifices diameters $\left(\mathrm{d}_{\mathrm{s}}\right): 3,5$ and $8 \mathrm{~mm}$. Five different outlets angles have been used $(\beta): 7^{\circ}, 10^{\circ}, 15^{\circ}, 21^{\circ}$, and $25^{\circ}$ ) with inlet angle $(\alpha)$ stabilization at $7^{\circ}$. The inlet and the outlet diameter (D) and throat length $\left(\mathrm{L}_{\mathrm{t}}\right)$ in all the experiments were constants and equals to 25 and $8 \mathrm{~mm}$, respectively. The air 
discharges and velocities were measured by using (Sigaro MF-700) with measuring accuracy $\pm 1 \%$ (see Figure 6).

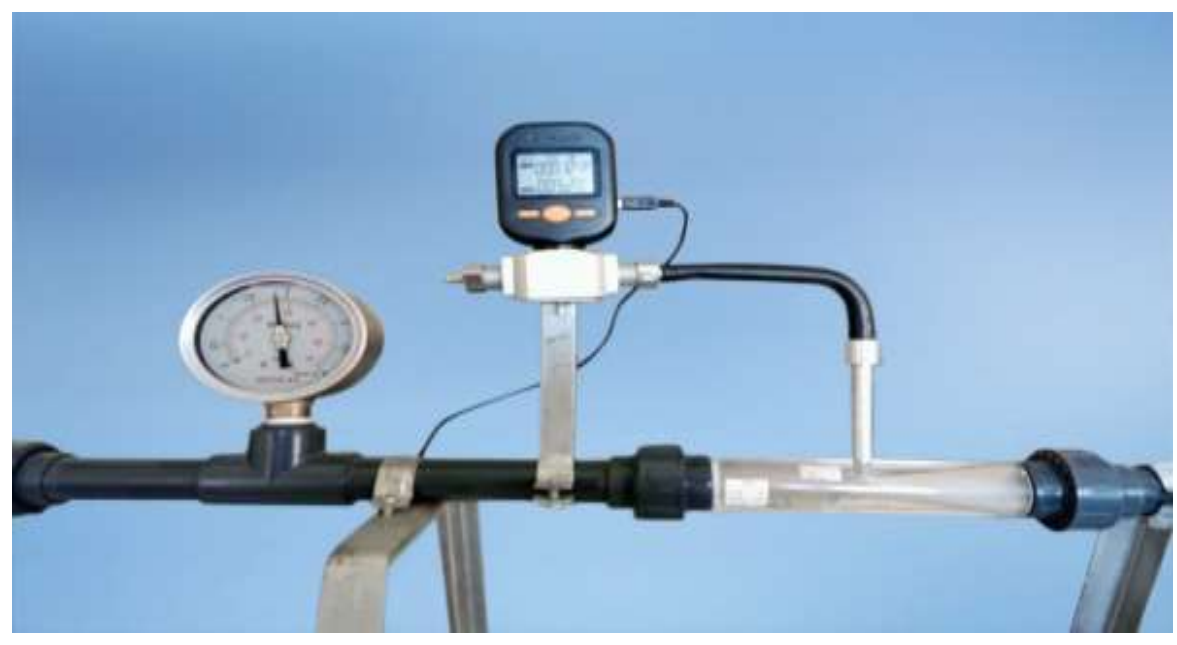

Figure 6. Real photos of the air flowmeter.

\section{RESULTS ANALYSIS AND DISCUSSIONS}

After performing the experimental work, measurements were recorded, and the evaluation were carried out. These measurements were represented in comparative way in which all tested parameters were plotted in the identical graph. In Figures 7 to 15, the values of Reynold's number $(\mathrm{Re})$ were plotted on the X-axis as independent variable and the ratio $\left(\mathrm{Q}_{\text {air }} / \mathrm{Q}_{\text {water }}\right)$ was set as dependent variable on the $\mathrm{Y}$-axis. The results will be deliberated underneath the followings: effect of outlet angel $(\beta)$, Reynold's number $(\mathrm{Re})$ in the throat part, ratio of $\left(\mathrm{d}_{\mathrm{s}} / \mathrm{D}\right)$ and ratio of $\left(\mathrm{L}_{\mathrm{t}} / \mathrm{D}\right)$ on the ratio $\left(\mathrm{Q}_{\text {air }} / \mathrm{Q}_{\text {water }}\right)$. Finally, Implementing design equations and charts to generalize all the tested parameters. Additionally, empirical equations were gotten for venturi tubes linking the ratio $\left(\mathrm{Q}_{\text {air }} / \mathrm{Q}_{\text {water }}\right)$ to throat lengths and diameters, venturi outlets angles, air inlets orifices diameters and Reynolds numbers.

From these Figures 7 to 15 it could be noticed that the ratio of $\left(\mathrm{Q}_{\text {air }} / \mathrm{Q}_{\text {water }}\right)$ increased with decreasing ratio of $\left(d_{t} / D\right)$. The cause for this is the increased pressure difference between the inlet and throat part. It was found from these figures that the change in the air inlet hole diameter affected the ratio of $\left(\mathrm{Q}_{\text {air }} / \mathrm{Q}_{\text {water }}\right)$, the ratio of $\left(\mathrm{Q}_{\text {air }} / \mathrm{Q}_{\text {water }}\right)$ increased with increasing the air inlet hole diameter. In other meaning, it was remarked from the results that the ratio of $\left(\mathrm{Q}_{\text {air }} / \mathrm{Q}_{\text {water }}\right)$ increased with an increasing ratio of $\left(\mathrm{d}_{\mathrm{s}} / \mathrm{D}\right)$. It was observed also, that the ratio of $\left(\mathrm{Q}_{\text {air }} / \mathrm{Q}_{\text {water }}\right)$ decreased with increasing $(\mathrm{Re})$. However, the ratio of $\left(\mathrm{Q}_{\text {air }} / \mathrm{Q}_{\text {water }}\right)$ increased as 
the angle of the pipe downstream of the venturi tube, $\beta$, increased. The main cause for this is the increased pressure difference between the throat part and the outlet.

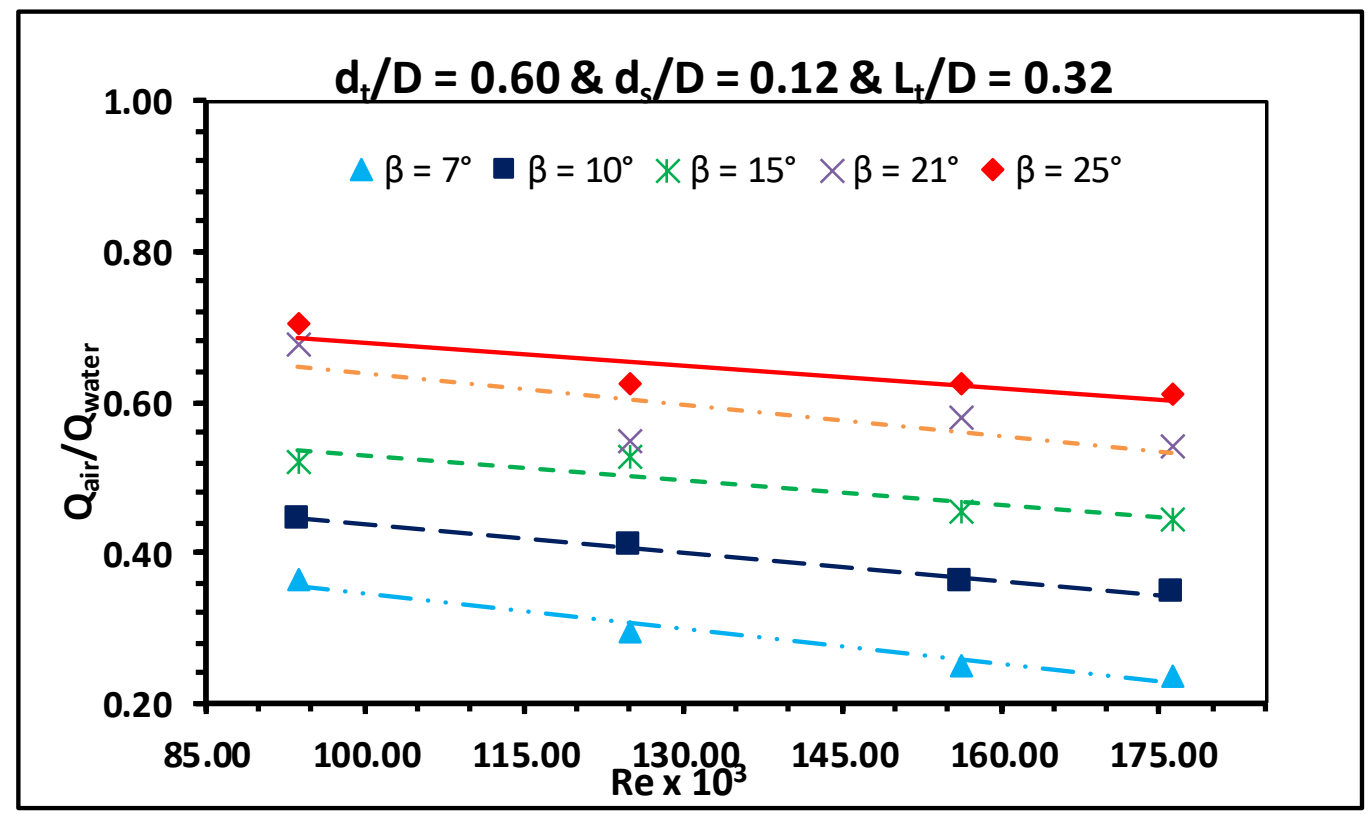

Figure 7. Relationship between Reynold's Number (Re) in the throat part and $\left(Q_{\text {air }} / Q_{\text {water }}\right)$ for different outlets angles $\left(a t d_{t} / D=0.60 \& d_{s} / D=0.12 \& L_{t} / D=0.32\right)$.

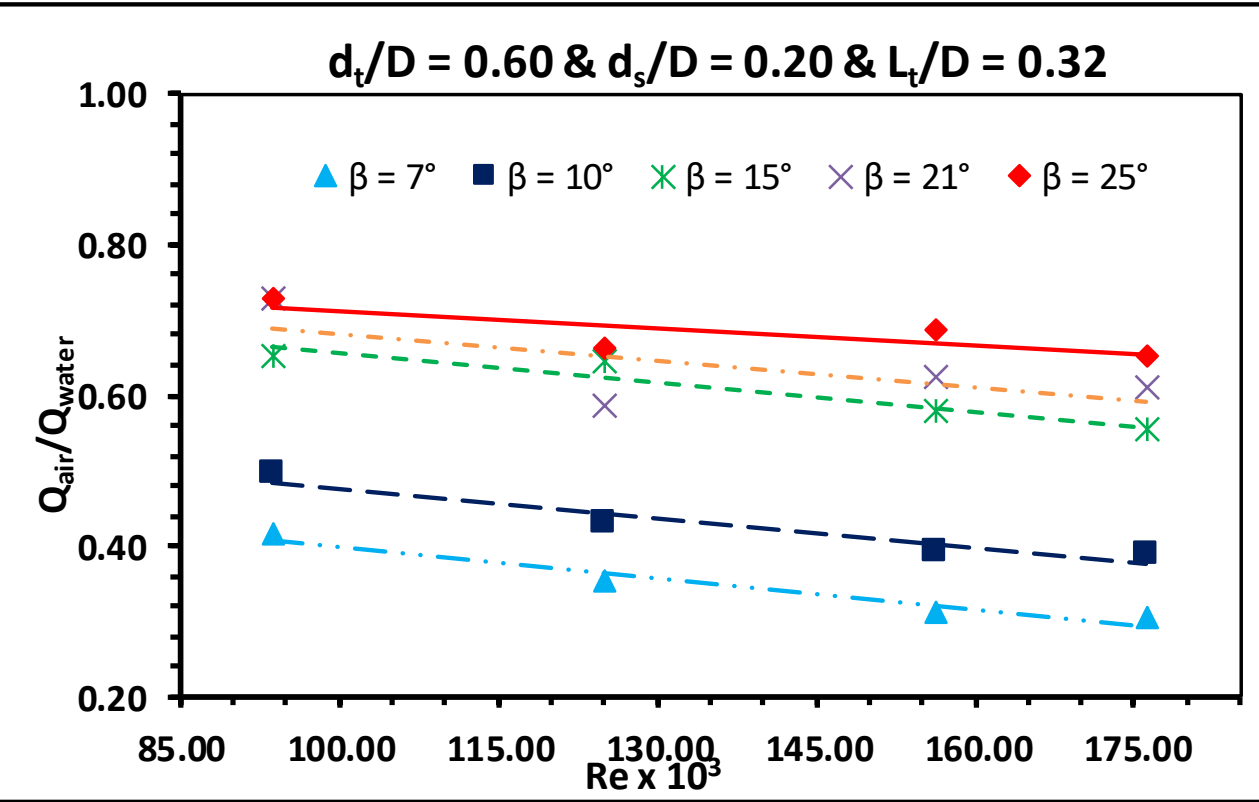

Figure 8. Relationship between Reynold's Number $(\mathrm{Re})$ in the throat part and $\left(Q_{\text {air }} / Q_{\text {water }}\right)$ for different outlets angles $\left(a_{t} d_{t} / D=0.60 \& d_{s} / D=0.20 \& L_{t} / D=0.32\right)$. 


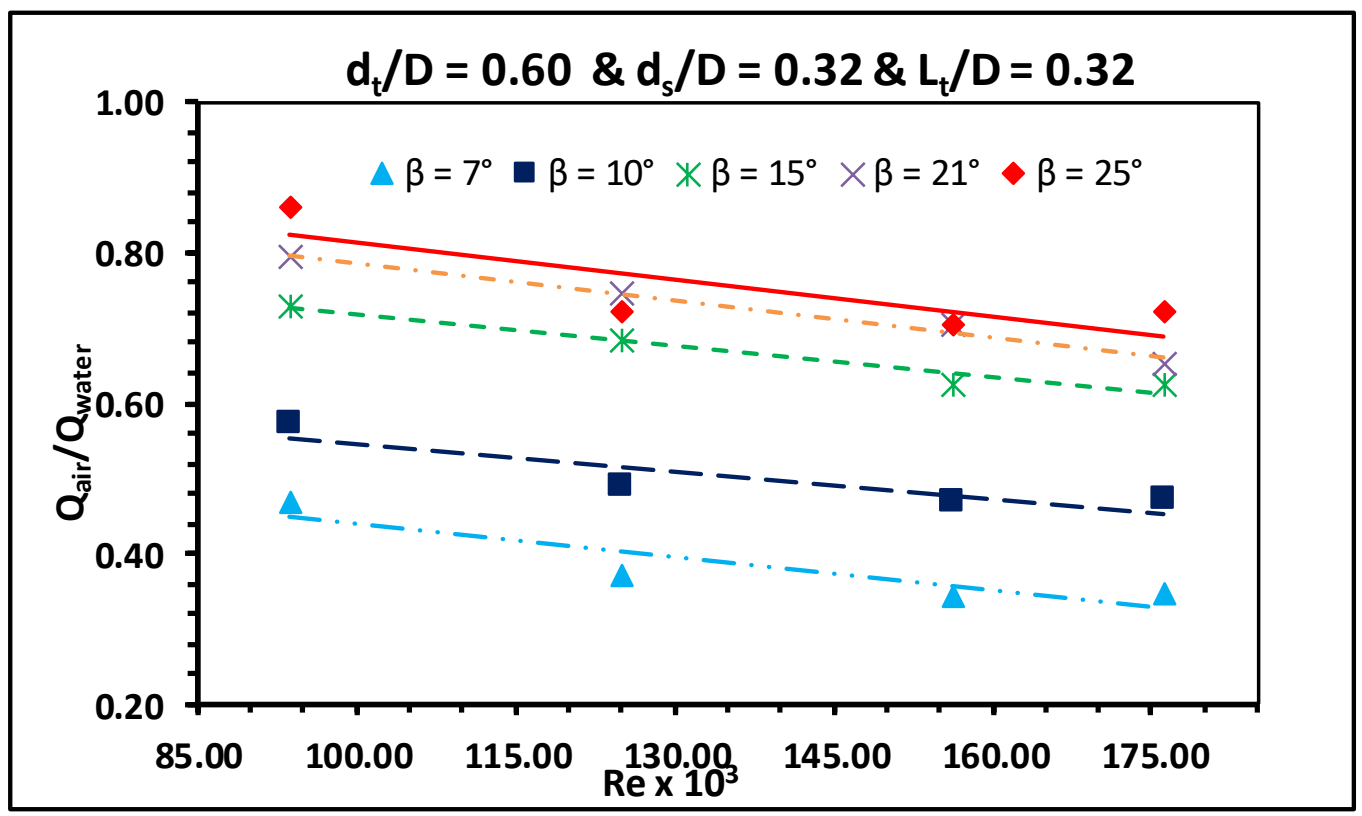

Figure 9. Relationship between Reynold's Number $(\mathrm{Re})$ and $\left(\mathrm{Q}_{\text {air }} / \mathrm{Q}_{\text {water }}\right)$ for different outlets angles $\left(\right.$ at $\left.d_{t} / D=0.60 \& d_{s} / D=0.32 \& L_{t} / D=0.32\right)$.

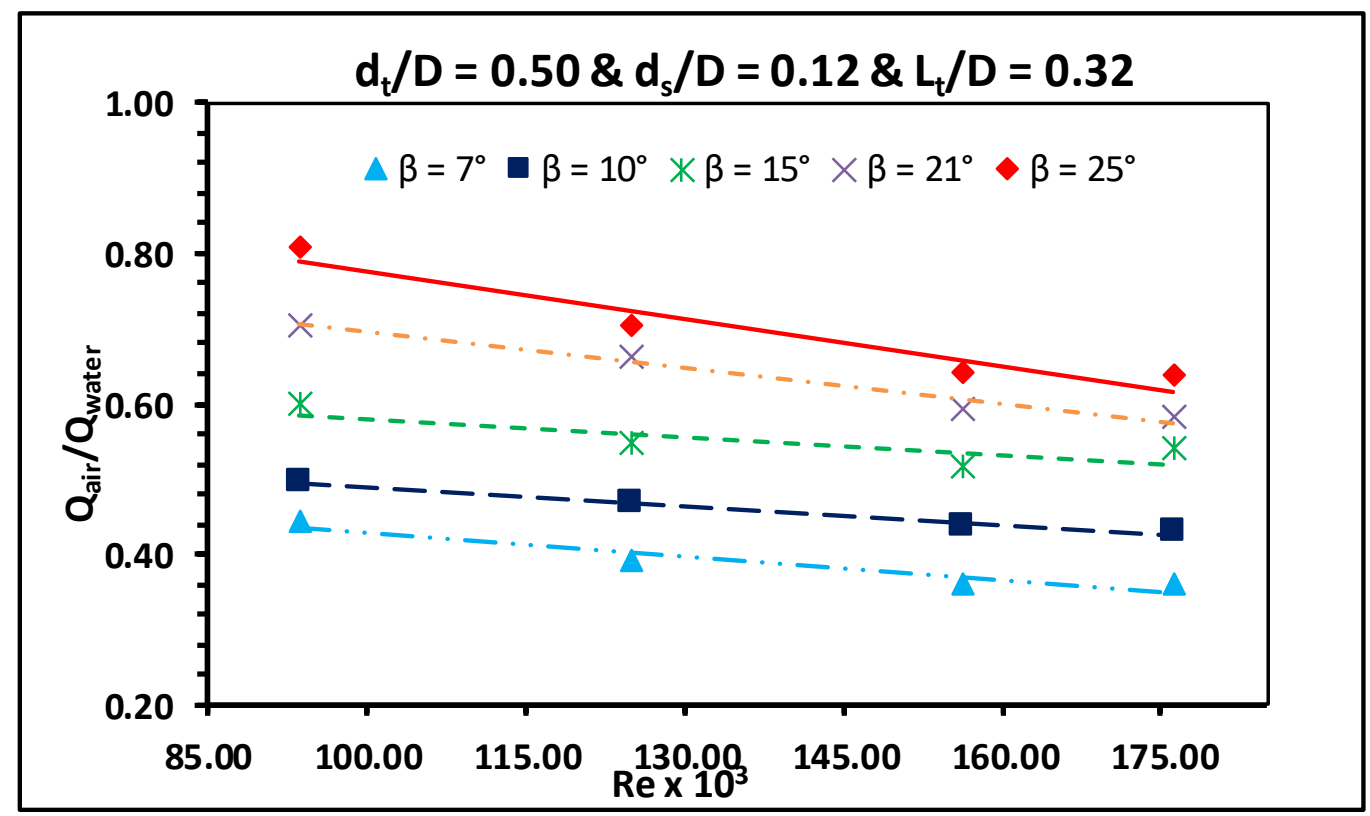

Figure 10. Relationship between Reynold's Number (Re) in the throat part and $\left(Q_{\text {air }} / Q_{\text {water }}\right)$ for different outlets angles $(a t d t / D=0.50 \& d s / D=0.12 \& L / D=0.32)$. 


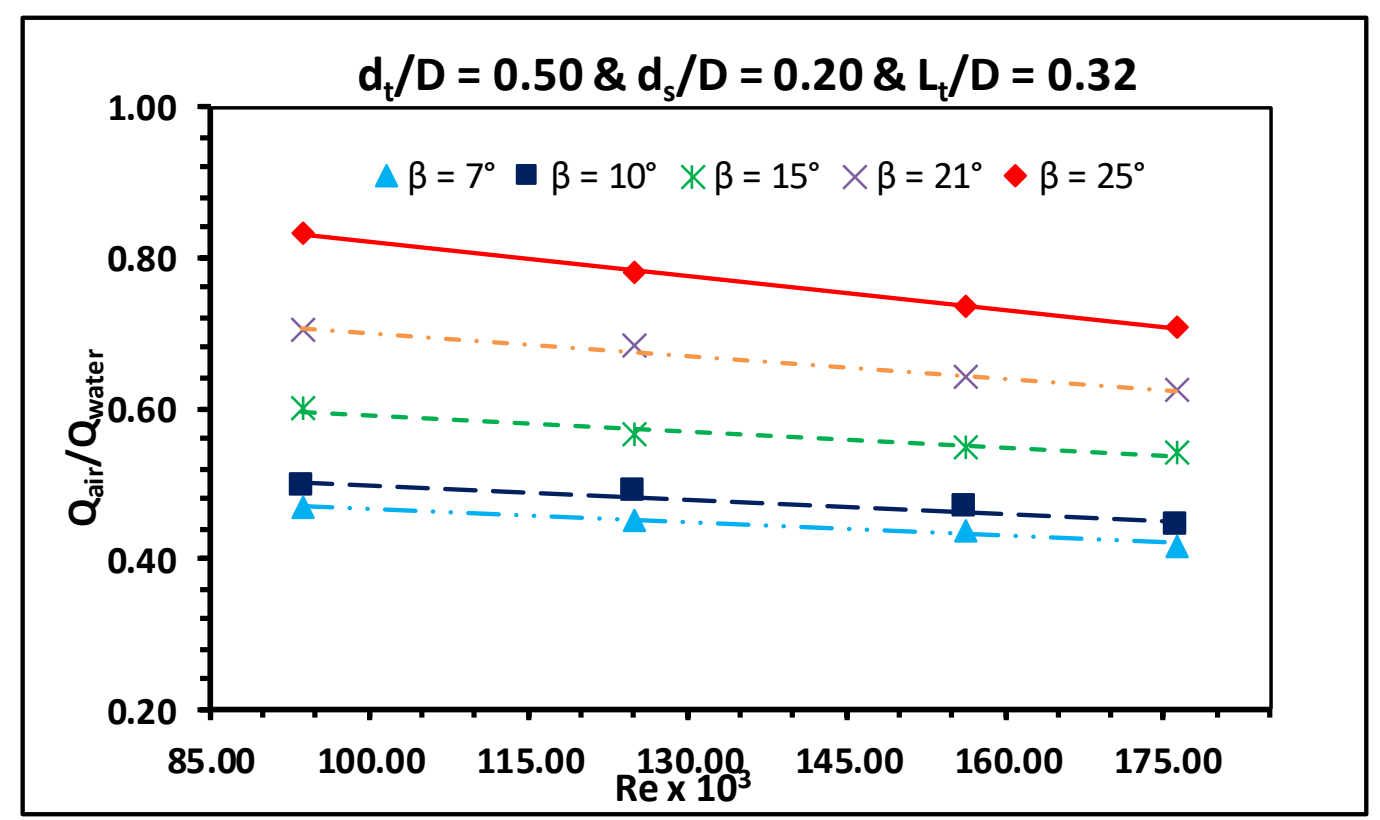

Figure 11. Relationship between Reynold's Number (Re) in the throat part and $\left(Q_{\text {air }} / Q_{\text {water }}\right)$ for different outlets angles $\left(\right.$ at $\left.d_{t} / D=0.50 \& d_{s} / D=0.20 \& L_{t} / D=0.32\right)$.

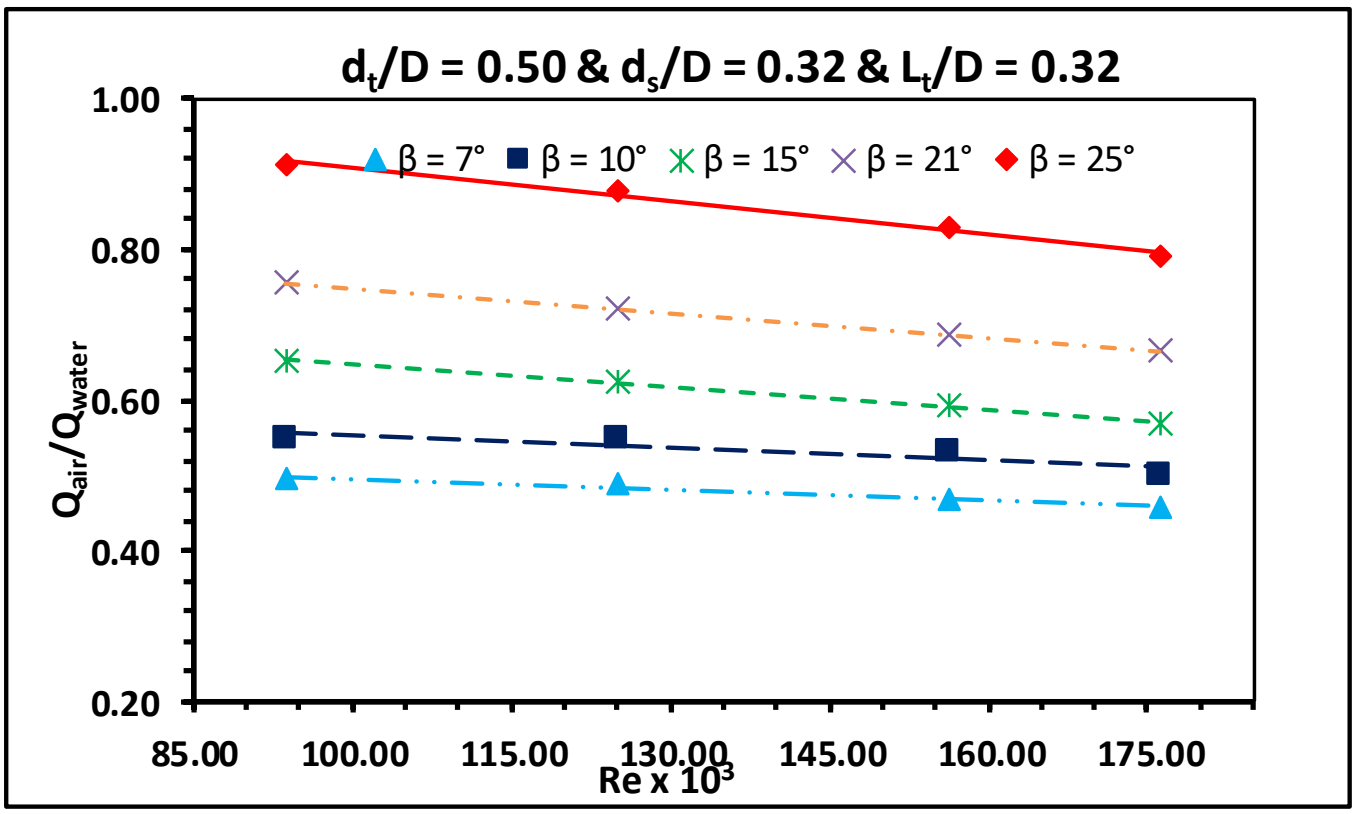

Figure 12. Relationship between Reynold's Number $(\mathrm{Re})$ in the throat part and $\left(Q_{\text {air }} / Q_{\text {water }}\right)$ for different outlets angles $\left(\right.$ at $\left.d_{t} / D=0.50 \& d_{s} / D=0.32 \& L_{t} / D=0.32\right)$. 


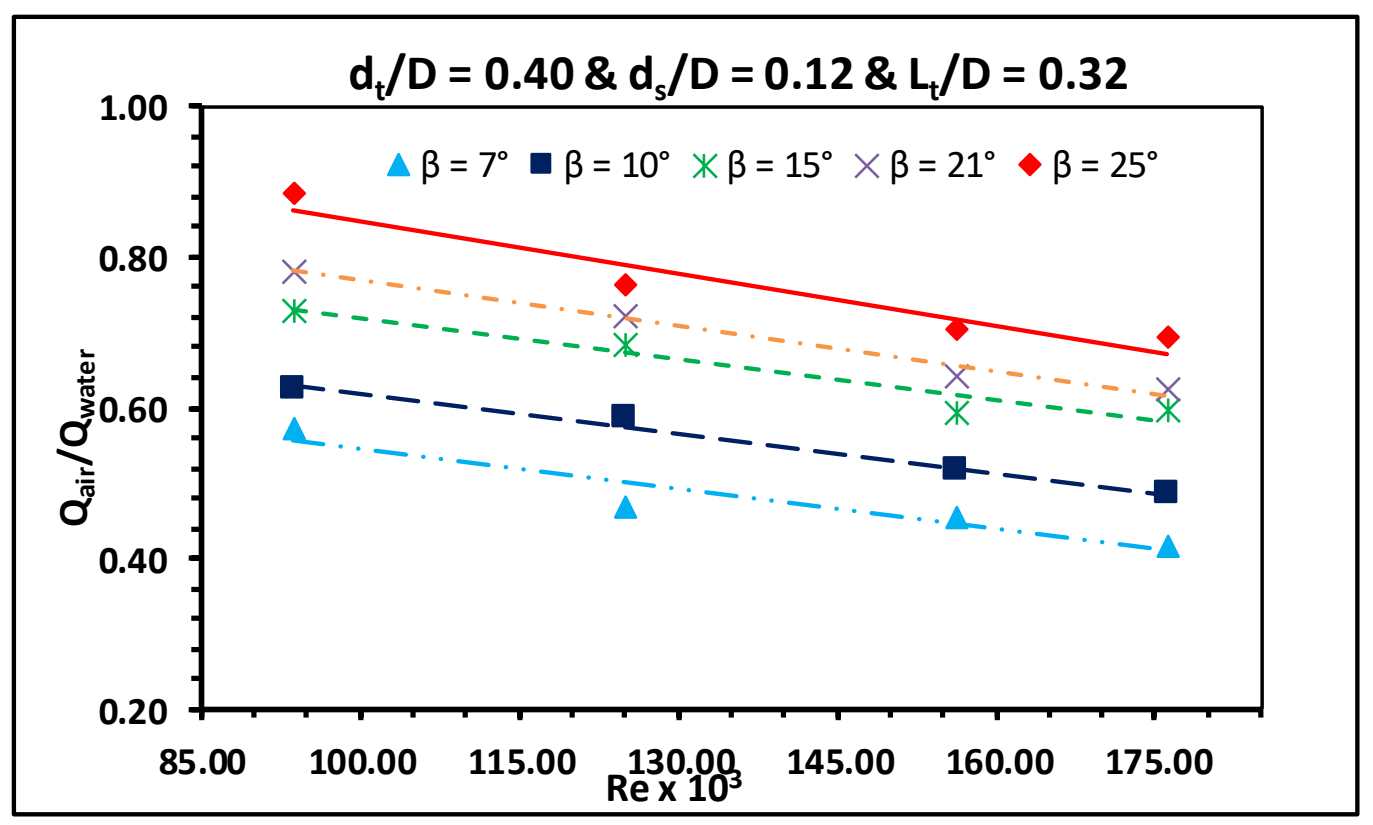

Figure 13. Relationship between Reynold's Number (Re) in the throat part and $\left(Q_{\text {air }} / Q_{\text {water }}\right)$ for different outlets angles $\left(a t d_{t} / D=0.40 \& d_{s} / D=0.12 \& L_{t} / D=0.32\right)$.

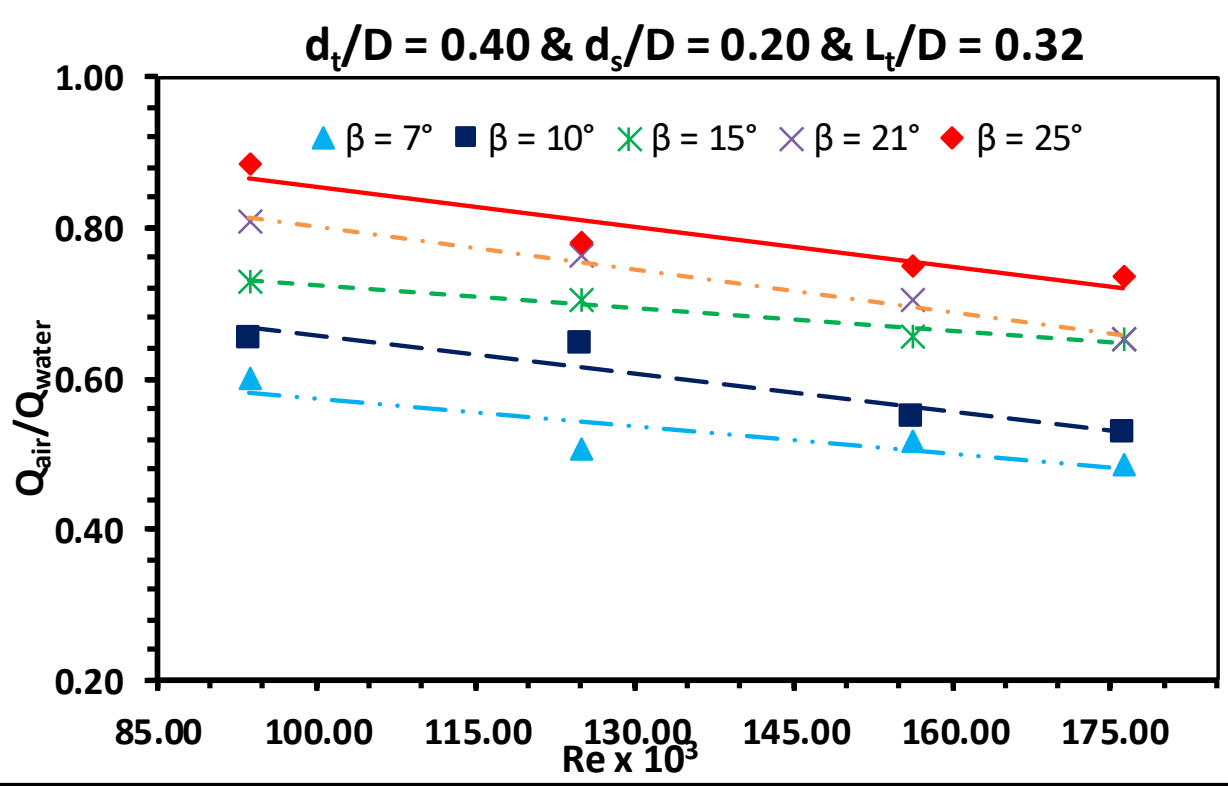

Figure 14. Relationship between Reynold's Number $(\mathrm{Re})$ in the throat part and $\left(Q_{\text {air }} / Q_{\text {water }}\right)$ for different outlets angles $\left(\right.$ at $\left.d_{t} / D=0.40 \& d_{s} / D=0.20 \& L_{t} / D=0.32\right)$. 


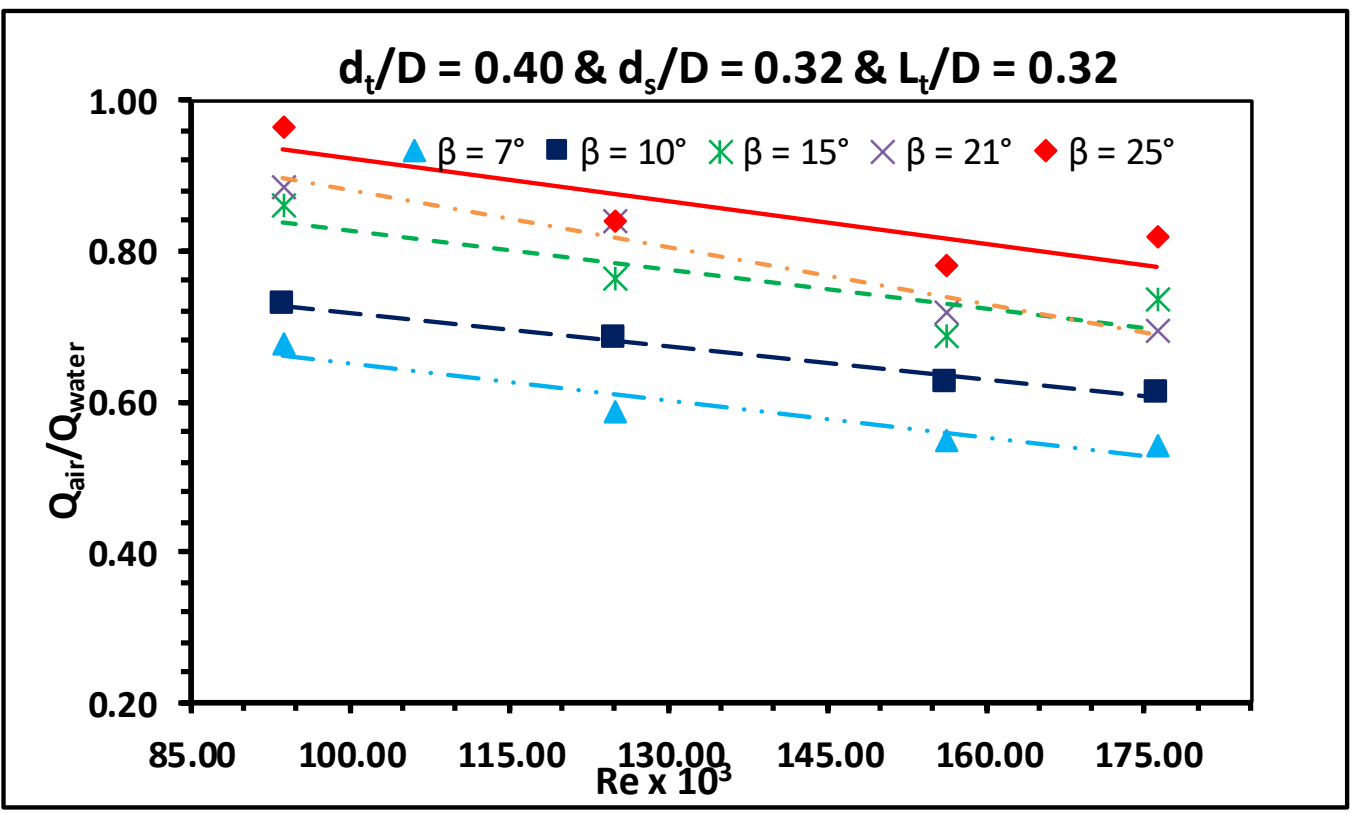

Figure 15. Relationship between Reynold's Number (Re) in the throat part and $\left(Q_{\text {air }} / Q_{\text {water }}\right)$ for different outlets angles $\left(a_{t} d_{t} / D=0.40 \& d_{s} / D=0.32 \& L_{t} / D=0.32\right)$.

\section{DESIGN EQUATIONS AND CHARTS}

It is important to associate the factors that may influence the ratio $\left(\mathrm{Q}_{\mathrm{air}} / \mathrm{Q}_{\mathrm{water}}\right)$ into a general formula. The importance of these formulas lies in its being suitable for design purpose. To achieve this objective, liner regression was applied to the experimental results, the following shows sample of the deduced empirical equations and correlation coefficients " $\mathrm{R}$ ":

Equations for calculating $Q_{\text {air }} / Q_{\text {water }}$ at $d_{t} / D=0.60 \& d_{s} / D=0.12 \& L_{t} / D=0.32$ :

$$
\begin{array}{lll}
\underline{\text { For }\left(\beta=7^{\circ}\right)} & \frac{Q_{\text {air }}}{Q_{\text {urnthr }}}=-0.0016 \operatorname{Re}+0.5021 & \mathrm{R}^{2}=0.96 \\
\underline{\text { For }\left(\beta=25^{\circ}\right)} & \frac{Q_{\text {air }}}{Q_{\text {wrathr }}}=-0.0010 \mathrm{Re}+0.7825 & \mathrm{R}^{2}=0.87
\end{array}
$$

Equations for calculating $Q_{\text {air }} / Q_{\text {water }}$ at $d_{t} / D=0.60 \& d_{s} / D=0.20 \& L_{t} / D=0.32$ :

$$
\underline{\text { For }\left(\beta=7^{\circ}\right)} \quad \frac{Q_{\text {air }}}{Q_{\text {wrater }}}=-0.0014 \operatorname{Re}+0.5357 \quad \mathrm{R}^{2}=0.95
$$


$\underline{\text { For }\left(\beta=25^{\circ}\right)} \quad \frac{Q_{\text {air }}}{Q_{\text {wrater }}}=-0.0007 \operatorname{Re}+0.7825 \quad \mathrm{R}^{2}=0.71$

Equations for calculating $Q_{\text {air }} / Q_{\text {water }}$ at $d_{t} / D=0.60 \& d_{s} / D=0.32 \& L / D=0.32$ :

$\begin{array}{lll}\underline{\text { For }\left(\beta=7^{\circ}\right)} & \frac{Q_{\text {air }}}{Q_{\text {water }}}=-0.0015 \operatorname{Re}+0.5849 & \mathrm{R}^{2}=0.85 \\ \underline{\text { For }\left(\beta=25^{\circ}\right)} & \frac{Q_{\text {air }}}{Q_{\text {wrater }}}=-0.0017 \operatorname{Re}+0.6767 & \mathrm{R}^{2}=0.86\end{array}$

Equations for calculating $Q_{\text {air }} / Q_{\text {water }}$ at $d_{t} / D=0.50 \& d_{s} / D=0.12 \& L t / D=0.32$ :

$$
\begin{array}{lll}
\underline{\text { For }\left(\beta=7^{\circ}\right)} & \frac{Q_{\text {air }}}{Q_{\text {wrater }}}=-0.0010 \operatorname{Re}+0.5302 & \mathrm{R}^{2}=0.92 \\
\underline{\text { For }\left(\beta=25^{\circ}\right)} & \frac{Q_{\text {air }}}{Q_{\text {wrater }}}=-0.0021 \operatorname{Re}+0.7825 & \mathrm{R}^{2}=0.85
\end{array}
$$

Equations for calculating $Q_{\text {air }} / Q_{\text {water }}$ at $d_{t} / D=0.50 \& d_{s} / D=0.20 \& L_{t} / D=0.32$ :

$$
\begin{array}{lll}
\underline{\text { For }\left(\beta=7^{\circ}\right)} & \frac{Q_{\text {air }}}{Q_{\text {wrater }}}=-0.0006 \operatorname{Re}+0.5260 & \mathrm{R}^{2}=0.97 \\
\underline{\text { For }\left(\beta=25^{\circ}\right)} & \frac{Q_{\text {air }}}{Q_{\text {wrater }}}=-0.0015 \operatorname{Re}+0.9758 & \mathrm{R}^{2}=0.99
\end{array}
$$

Equations for calculating $Q_{\text {air }} / Q_{\text {water }}$ at $d_{t} / D=0.50 \& d_{s} / D=0.32 \& L_{t} / D=0.32$ :

$\underline{\text { For }\left(\beta=7^{\circ}\right)} \quad \frac{Q_{\text {air }}}{Q_{\text {urat:rr }}}=-0.0005 \operatorname{Re}+0.5420 \quad \mathrm{R}^{2}=0.96$

$\underline{\text { For }\left(\beta=25^{\circ}\right)} \quad \frac{Q_{\text {air }}}{Q_{\text {wrater }}}=-0.0015 \operatorname{Re}+0.9800 \quad \mathrm{R}^{2}=0.98$

Equations for calculating $Q_{\text {air }} / Q_{\text {water }}$ at $d_{t} / D=0.40 \& d_{s} / D=0.12 \& L_{t} / D=0.32$ :

$$
\begin{array}{lll}
\underline{\text { For }\left(\beta=7^{\circ}\right)} & \frac{Q_{\text {air }}}{Q_{\text {wratar }}}=-0.0018 \operatorname{Re}+0.7208 & \mathrm{R}^{2}=0.90 \\
\underline{\text { For }\left(\beta=25^{\circ}\right)} & \frac{Q_{\text {air }}}{Q_{\text {watrr }}}=-0.0023 \operatorname{Re}+1.0835 & \mathrm{R}^{2}=0.93
\end{array}
$$

Equations for calculating $Q_{\text {air }} / Q_{\text {water }}$ at $d_{t} / D=0.40 \& d_{s} / D=0.20 \& L_{t} / D=0.32$ :

$$
\underline{\text { For }\left(\beta=7^{\circ}\right)} \quad \frac{Q_{\text {air }}}{Q_{\text {wrater }}}=-0.0012 \operatorname{Re}+0.6939 \quad \mathrm{R}^{2}=0.82
$$

592Equations for calculating $Q_{\text {air }} / Q_{\text {water }}$ at $d_{t} / D=0.40 \& d_{s} / D=0.32 \& L_{t} / D=$ 0.32:

$\underline{\text { For }\left(\beta=7^{\circ}\right)} \quad \frac{Q_{\text {air }}}{Q_{\text {wrater }}}=-0.0017 \operatorname{Re}+0.8157 \quad \mathrm{R}^{2}=0.91$ 


$$
\underline{\text { For }\left(\beta=25^{\circ}\right)} \quad \frac{Q_{\text {air }}}{Q_{\text {uratar }}}=-0.0019 \operatorname{Re}+1.1104 \quad \mathrm{R}^{2}=0.79
$$

\section{CONCLUSIONS}

Based on the above investigations, the conclusions are as follows:

1- It was observed also, that the ratio of $\left(\mathrm{Q}_{\text {air }} / \mathrm{Q}_{\text {water }}\right)$ increased with decreasing ratio of $\left(d_{t} / D\right)$.

2- The ratio of $\left(\mathrm{Q}_{\text {air }} / \mathrm{Q}_{\text {water }}\right)$ increased with an increasing ratio of $\left(\mathrm{d}_{\mathrm{s}} / \mathrm{D}\right)$.

3- For all tested angles $\beta$, ratios of $(\mathrm{ds} / \mathrm{D})$ and $\left(\mathrm{d}_{\mathrm{t}} / \mathrm{D}\right)$, $\left(\mathrm{Q}_{\text {air }} / \mathrm{Q}_{\text {water }}\right)$ decreased with increasing $(\mathrm{Re})$.

4- The ratio of $\left(\mathrm{Q}_{\mathrm{air}} / \mathrm{Q}_{\text {water }}\right)$ increased as the angle of the pipe downstream of the venturi tube, $\beta$, increased.

5- The best results were given for the relationship between (Qair / Qwater) $=92 \%$ with outlet angle of $25^{\circ}$ in the case of $(\mathrm{dt} / \mathrm{D}=0.4$ and $\mathrm{ds} / \mathrm{D}=0.32$ and $\mathrm{Lt} / \mathrm{D}=0.32)$.

6- Empirical equations were gotten for venturi tubes linking the ratio of $\left(\mathrm{Q}_{\text {air }} / \mathrm{Q}_{\text {water }}\right)$ to throat lengths and diameters, venturi outlets angles, air inlets orifices diameters and Reynolds numbers.

\section{REFERENCES}

[1] Bagatur, T. 2005. Minimal conditions for venturi aeration of water flows. Proceedings of the Institution of Civil Engineers - Water Management, Vol. 158, No. WM3, pp. 127-130.

[2] Bagatur, T., Onen, F. and Kayaalp, N. 2018. Testing of System Performance for Different Aerator Configuration Using Venturi. El-Cezerî Journal of Science and Engineering Vol: 5, No: 3, (724-733) DOI : 10.31202/ecjse.402032.

[3] Baylar, A., Ozkan F. and Unsal, M. 2009. Effect of air inlet hole diameter of venturi tube on air injection rate. KSCE Journal of Civil Eng., Vol. 14 (4): 489-492.

[4] Dam, A. K. and Sarkar, S. 2015. Performance evaluation of venturi aerator for different throat hole parameters. Journal of Agroecology and Natural Resource Management Print ISSN: 2394-0786, Online ISSN: 2394-0794, Volume 2, Number 3; pp. 220-225. 
[5] Daugherty, R. L., Franzini, J. B., and Finnemore, E. J. 1985. Fluid mechanics with engineering applications. McGraw-Hill, Inc., New York.

[6] Emiroglu, M. E. and Baylar A. 2003. Role of Nozzles with Air Holes in Air Entrainment by $a$ Water Jet. Water Quality Research Journal of Canada, 38 (4), 785-795.

[7] Khound, A., Yadav, A., Sarkar, S. and Kumar, A. 2017. Influence of Throat Length and Flow Parameters on a Venturi as an Aerator. International Journal of Agriculture, Environment and Biotechnology. Citation: IJAEB: 10 (6): 717-723, DOI: 10.5958/2230732X.2017.00089.4.

[8] Li, H., Li, H., Huang, X., Han, Q., Yuan, Y. and Qi, B. 2020. Numerical and Experimental Study on the Internal Flow of the Venturi Injector. Processes 2020, 8, 64; doi:10.3390/pr8010064.

[9] Nithin, T., Jain, N. and Hiriyannaiah, A. 2012. Optimization of venturi flow meter model for the angle of divergence with minimal pressure drop by computational fluid dynamics method. International Conference on Challenges and Opportunities in Mechanical Engineering, Industrial Engineering and Management Studies 658 (ICCOMIM - 2012), $11-13$.

[10] Reader-Harris, M. J., Brunton, W. C., Gibson, J. J., Hodges, D. and Nicholson, I. G. 2001. Discharge coefficients of Venturi tubes with standard and non-standard convergent angles. Flow Measurement and Instrumentation, Vol. 12, Issue 2, Pages 135-145.

[11] Sobenko, L. R., Frizzone, J. A., de Camargo, A. P., Saretta, E. and da Rocha, H. S. 2019. Characterization of venturi injector using dimensional analysis. R. Bras. Eng. Agríc. Ambiental, v.23, n.7, p.484-491.

[12] Zhang, J. X. 2017. Analysis on the effect of venturi tube structural parameters on fluid flow. AIP Advances 7, 065315, Vol. 7, Issue $6.10 .1063 / 1.4991441$.

[13] Zhu, J., Miller, C. F., Dong, C., Wu, X., Wang, L. and Mukhtar S. 2007. Aerator module development using venturi air injectors to improve aeration efficiency. Applied Eng. Agricul., Vol. 23: 661-667 